\title{
Brak możliwości wypowiadania się przez organ odwoławczy w decyzji kasacyjnej wydanej na podstawie art. 138 § 2 K.p.a. o ewentualnym naruszeniu prawa materialnego lub interesu prawnego strony skarżącej. Glosa aprobująca do wyroku Naczelnego Sądu Administracyjnego z dnia 17 kwietnia 2018 r., II OSK 1781/17
}

Inability to make an appeal by the appeal body in a cassation decision issued pursuant to art. $138 \S 2$ of the Code of Administrative Procedure of a possible violation of the substantive law or the legal interest of the party to administrative proceedings. Gloss to the judgment of the Supreme Administrative Court of 17 April 2018, II OSK 1781/17

Отсутствие возможности для апелляционной инстанции высказаться в кассационном определении, вынесенном в соответствии со статьей 138 § 2 Административно-процессуального кодекса, о возможном нарушении норм материального права или законных интересов заявителя. Одобрительный комментарий к постановлению Высшего Административного Суда от 17 апреля 2018 года, II OSK 1781/17

\author{
PRZEMYSŁAW ZDYB \\ Dr, Uniwersytet Szczeciński \\ e-mail: przemyslaw.zdyb@usz.edu.pl, https://orcid.org/0000-0002-2068-4556
}

\begin{abstract}
Streszczenie: W glosowanym wyroku Naczelnego Sądu Administracyjnego poruszono problem wypowiadania się przez organ odwoławczy w decyzji kasacyjnej wydanej na podstawie art. 138 § 2 K.p.a. w przedmiocie ewentualnego naruszenia prawa materialnego lub interesu prawnego strony skarżącej przez organ pierwszej instancji. NSA słusznie zauważył, że na podstawie tego artykułu organ odwoławczy nie rozstrzyga o meritum sprawy, nie przeprowadza merytorycznej kontroli decyzji wydanej przez organ pierwszej instancji, gdyż wydając decyzję kasacyjną (która ma charakter formalny), wskazuje na konieczność przeprowadzenia w określonym zakresie lub w całości postępowania wyjaśniającego, celem poczynienia ustaleń niezbędnych do prawidłowego rozstrzygnięcia sprawy. W tej sytuacji organ odwoławczy nie może wypowiadać się o ewentualnym naruszeniu prawa materialnego lub interesu prawnego strony skarżącej. Decyzja kasacyjna nie może bowiem spowodować niekorzyści „materialnej” dla strony.
\end{abstract}

Słowa kluczowe: postępowanie administracyjne, decyzje organu odwoławczego, decyzja kasacyjna

Summary: The commentary presents the analysis of the judgment of the Supreme Administrative Court of 17 April 2018, II OSK 1781/17, which concerns the pronounce making an appeal by the appeal body in a cassation decision issued pursuant to art. $138 \S 2$ of the Code of Administrative Procedure on the possible violation of the substantive law or the legal interest of the party to administrative proceedings by the first-instance decision-maker. The Supreme Administrative Court rightly noted that on the basis of this article, the appeal body 
does not decide on the merits of the case and does not carry out substantive control of the decision issued by the first instance body because by issuing a cassation decision (which has a formal nature) it indicates the necessity to carry out explanatory proceedings in a given scope or in its entirety, in order to make the necessary arrangements for the correct settlement of the case. In this situation, the appeal body cannot comment on a possible violation of the substantive law or the legal interest of the party to administrative proceedings. A cassation decision may not cause material disadvantage for the party.

Key words: administrative proceedings, decisions of the appeal body, cassation decision

Резюме: В комментируемом постановлении Высшего Административного Суда рассматривается проблема возможности высказываться апелляционной инстанцией в кассационном определении, вынесенном в соответствии со статьей 138 § 2 Административно-процессуального кодекса, о возможном нарушении материального права или законного интереса заявителя органом первой инстанции. Высший Административный Суд справедливо указал, что в соответствии с данной статьей апелляционная инстанция не решает вопрос о существе дела, не осуществляет контроль по существу решения, вынесенного органом первой инстанции, поскольку, вынося кассационное определение (которое носит формальный характер), она указывает на необходимость проведения разъяснительной процедуры в определенном объеме или в целом для принятия необходимых мер для правильного разрешения дела. В такой ситуации апелляционная инстанция не может высказываться о возможном нарушении норм материального права или законного интереса заявителя. Это связано с тем, что кассационное определение не может причинить «имущественный» вред стороне.

Ключевые слова: административное производство, решения апелляционной инстанции, кассационное определение

Organ odwoławczy nie powinien wypowiadać się w decyzji kasacyjnej wydanej na podstawie art. $138 \$ 2$ Kodeksu postępowania administracyjnego (dalej: K.p.a.) o ewentualnym naruszeniu prawa materialnego lub interesu prawnego strony skarżącej ${ }^{1}$.

Przedmiotem rozważań poniżej przedstawionej glosy jest wyrok Naczelnego Sądu Administracyjnego z dnia 17 kwietnia 2018 r., II OSK 1781/17, CBOSA². NSA rozpoznawał skargę kasacyjną od wyroku Wojewódzkiego Sądu Administracyjnego (dalej: WSA) w Olsztynie z dnia 21 lutego 2017 r., II SA/Ol 1377/16, CBOSA, w sprawie ze skarg M.R. oraz [...] sp. z o.o. z siedzibą w W. (dalej Spółka) na decyzję Wojewody Warmińsko-Mazurskiego z dnia [...] października 2016 r. nr [...] $\mathrm{w}$ przedmiocie pozwolenia na budowę.

Głównym elementem sporu w przedmiotowej sprawie były dwie grupy zagadnień. Pierwsza z nich koncentrowała się wokół możliwości wydania decyzji o pozwoleniu na budowę na część zamierzenia budowlanego w postaci budowy elektrowni wiatrowej bez przyłącza na podstawie art. 33 ust. 1 ustawy - Prawo budowlane. Druga grupa zagadnień wiązała się z kwestiami dotyczącymi możliwości ustalenia kręgu stron postępowania administracyjnego w postępowaniu o wydanie

Teza stanowi wybór autora.

Dostępne w Centralnej Bazie Orzeczeń Sądów Administracyjnych na stronie www.orzeczenia.nsa.gov.pl (dalej: CBOSA). 
decyzji o pozwoleniu na budowę przez organ odwoławczy w uzasadnieniu decyzji kasacyjnej. Przedmiotem analizy odnoszącej się do glosowanego orzeczenia będzie jedynie wskazana przez NSA kwestia granic orzekania organu odwoławczego na podstawie art. $138 \$ 2$ K.p.a. Jest to bowiem niewątpliwie zagadnienie ważkie, o dużym znaczeniu praktycznym.

Glosowane orzeczenie zapadło w następującym stanie faktycznym. Decyzją nr [...] z dnia [...] lipca 2016 r. Starosta Nowomiejski zatwierdził projekt budowlany i udzielił pozwolenia na budowę dla [...] sp. z o.o. z siedzibą w W. Odwołania od powyższej decyzji wnieśli A.P. oraz E. i Z.K., K.K. oraz K.K., a także M.A. Decyzją z dnia [...] października 2016 r. Wojewoda Warmińsko-Mazurski na podstawie art. $138 \$ 2$ K.p.a. uchylił w całości zaskarżoną decyzję i przekazał sprawę organowi pierwszej instancji do ponownego rozpatrzenia. Wojewoda wskazał m.in., że w sprawie nieprawidłowo ustalono krąg stron postępowania oraz brak jest ujęcia we wniosku o pozwolenie na budowę - i co za tym idzie decyzji o pozwoleniu na budowę - sąsiedniej działki nr [...]. Organ odwoławczy zauważył, że z projektu budowlanego wynika, iż wieża elektrowni usytuowana jest na działce nr [...], jednak śmigło o długości $54 \mathrm{~m}$ „zachodzi” (omiata), część działki nr [...].

Skargi na rozstrzygnięcie Wojewody wywiedli Spółka oraz M.R. Sąd pierwszej instancji swoim wyrokiem uchylił zaskarżoną decyzję Wojewody Warmińsko-Mazurskiego. WSA w Olsztynie w motywach swojego rozstrzygnięcia wyjaśnił m.in., że Wojewoda błędnie wywiódł, w okolicznościach faktycznych i prawnych sprawy, iż ustalając obszar oddziaływania inwestycji, należy stosować art. 28 K.p.a., a nie art. 28 ust. 2 ustawy z dnia 7 lipca 1994 r. - Prawo budowlane (Dz. U. z 2016 r. poz. 290). W ocenie sądu nie było w przedmiotowej sprawie żadnych przesłanek do zastosowania tego przepisu K.p.a., bowiem kwestie strony w postępowaniu w sprawie pozwolenia na budowę rozstrzyga art. 28 ustawy - Prawo budowlane. Podniósł także, że w przedmiotowej sprawie ma zastosowanie art. 28 ust. 2 ww. ustawy, a nie jego ust. 4. Skargi kasacyjne od powyższego wyroku WSA w Olsztynie wywiedli Wojewoda Warmińsko-Mazurski oraz M.R., kwestionując to orzeczenie w całości.

NSA wyrokiem z dnia 17 kwietnia 2018 r., II OSK 1781/17, CBOSA uchylił zaskarżony wyrok i oddalił wniesione skargi do WSA w Olsztynie. Na wstępie NSA wskazał, iż „W związku z treścią art. $138 \$ 2$ k.p.a., ustawowym warunkiem dopuszczalności uchylenia decyzji organu pierwszej instancji i przekazania temu organowi sprawy do ponownego rozpatrzenia jest łączne wystąpienie dwóch przesłanek: 1) naruszenie przez organ pierwszej instancji przepisów procesowych oraz - stanowiące konsekwencję tego naruszenia - 2) zaniechanie wyjaśnienia przez ten organ okoliczności faktycznych sprawy w stopniu wykraczającym poza uprawnienia organu odwoławczego, o których mowa w art. 136 k.p.a.. 
Następnie NSA słusznie zauważył, że „użyte w art. $138 \$ 2$ k.p.a. określenie «konieczny do wyjaśnienia zakres sprawy ma istotny wpływ na jej rozstrzygnięcie» jest określeniem wymagającym każdorazowo interpretacji na tle okoliczności faktycznych sprawy. W szczególności można stwierdzić, że nawiązuje ono do pojęcia «nieprzeprowadzenia przez organ pierwszej instancji postępowania wyjaśniającego w całości lub znacznej części», co - zgodnie z zasadą dwuinstancyjności postępowania administracyjnego - uniemożliwia rozstrzygnięcie sprawy przez organ odwoławczy. Istotne jest również i to, że orzekając na podstawie tego artykułu organ odwoławczy nie rozstrzyga o meritum sprawy. Nie przeprowadza też merytorycznej kontroli decyzji wydanej przez organ pierwszej instancji, gdyż wydając decyzję kasacyjną wskazuje właśnie na konieczność przeprowadzenia w określonym zakresie lub w całości postępowania wyjaśniającego, celem poczynienia ustaleń niezbędnych do prawidłowego rozstrzygnięcia sprawy. W tej sytuacji organ odwoławczy nie może wypowiadać się także o ewentualnym naruszeniu prawa materialnego lub interesu prawnego strony skarżącej. Decyzja kasacyjna nie może bowiem spowodować niekorzyści «materialnej» dla strony; może spowodować jedynie przedłużenie postępowania administracyjnego. Jak już wyżej wskazano, decyzja kasacyjna ma charakter procesowy, gdyż podstawą jej podjęcia jest wyłącznie naruszenie przepisów postępowania”.

W rezultacie NSA wyjaśnił, że „taki sposób rozstrzygnięcia zaskarżonej decyzji determinował również sposób przeprowadzenia jej kontroli legalności dokonywanej przez Sąd pierwszej instancji. Skoro decyzja kasacyjna jest w istocie rozstrzygnięciem procesowym, gdyż nie kształtuje ona stosunku materialnoprawnego, to możliwości rozpoznania i orzekania sądu administracyjnego podlegają w tych sytuacjach istotnemu ograniczeniu, albowiem sąd dokonuje kontroli legalności tego rodzaju rozstrzygnięcia $\mathrm{w}$ świetle ustawowych przesłanek określonych w art. 138 $\$ 2$ k.p.a. Kontrola ta nie może natomiast, co do zasady, obejmować sformułowania końcowej oceny materialnoprawnej związanej z istotą sprawy, gdyż formułowanie wniosków w tym zakresie byłoby przedwczesne i niedopuszczalne”. NSA kończąc rozważania dotyczące podstaw wydania decyzji kasacyjnej przez Wojewodę Warmińsko-Mazurskiego, wskazał jednocześnie, iż w okolicznościach rozpoznawanej sprawy uzasadnione było oddalenie wniesionych skarg na podstawie art. 151 ustawy - Prawo o postępowaniu przed sądami administracyjnymi, albowiem wydana decyzja $w$ trybie art. $138 \$ 2$ K.p.a. odpowiadała prawu, choć jednocześnie organ odwoławczy wadliwie uznał w niej, że w sprawie winien mieć zastosowanie wobec ustalenia stron postępowania art. 28 K.p.a. zamiast art. 28 ust. 2 ustawy - Prawo budowlane. NSA zgodził się ze stanowiskiem wyrażonym przez Wojewodę Warmińsko-Mazurskiego, który stwierdził, że decyzja udzielająca pozwolenia na budowę 
wydana została przedwcześnie, przed koniecznym uzupełnieniem dokumentacji projektowej o wymaganą zawartość projektu zagospodarowania terenu, czym dopuszczono się uchybień procesowych mających istotny wpływ na wynik sprawy. Zasadnie organ odwoławczy wskazał również w ocenie NSA, iż pozwolenie na budowę winno obejmować nie tylko działkę, na której zaprojektowano elektrownię wiatrową, lecz także działkę, nad którą częściowo będzie zachodziło śmigło tej elektrowni.

Przed przejściem do omówienia glosowanego orzeczenia zaznaczyć należy, że powyższy wyrok NSA zapadł w oparciu o przepisy ze stanu prawnego, gdy decyzja kasacyjna wydana na podstawie art. $138 \$ 2$ K.p.a. podlegała zaskarżeniu do sądu administracyjnego $\mathrm{w}$ drodze skargi, a nie jak obecnie $\mathrm{w}$ drodze sprzeciwu od tej decyzji ${ }^{3}$ Ponadto dodane zostały przepisy art. $138 \$ 2$ a i art. $138 \$ 2$ b K.p.a. Zgodnie z pierwszym z nich, jeżeli organ pierwszej instancji dokonał w zaskarżonej decyzji błędnej wykładni przepisów prawa, które mogą znaleźć zastosowanie w sprawie, w decyzji, o której mowa $\mathrm{w} \$ 2$, organ odwoławczy określa także wytyczne w zakresie wykładni tych przepisów. Z kolei art. $138 \$ 2$ b K.p.a. umożliwia wydanie przez organ odwoławczy po przeprowadzeniu postępowania wyjaśniającego w zakresie niezbędnym do rozstrzygnięcia sprawy decyzji na podstawie art. 138 $\S 1$ albo 4 K.p.a. ${ }^{4}$

Przystępując do analizy uzasadnienia glosowanego wyroku NSA, wskazać należy, że w doktrynie decyzje organu odwoławczego dzieli się na decyzje merytoryczne i kasacyjne (kasatoryjne) ${ }^{5}$. Do merytorycznych rozstrzygnięć organu odwoławczego zalicza się decyzje o utrzymaniu w mocy zaskarżonej decyzji (art. 138 $\$ 1$ pkt 1 K.p.a.) albo o uchyleniu zaskarżonej decyzji w całości lub w części i orzekającej w tym zakresie co do istoty sprawy (art. $138 \$ 1$ pkt 2 K.p.a. - decyzja merytoryczno-reformacyjna). Decyzjami kasacyjnymi natomiast są decyzje o uchyleniu decyzji organu pierwszej instancji i umorzeniu postępowania pierwszoinstancyjnego w całości albo w części (art. $138 \$ 1$ pkt 2 in fine K.p.a.), albo o przekazaniu sprawy do ponownego rozpatrzenia przez organ pierwszej instancji (art. 138 $\$ 2$ K.p.a.). Jak powszechnie przyjmuje się w doktrynie i literaturze, uprawnienia

3 Por. przepisy art. 64a - art. 64e ustawy z dnia 30 sierpnia 2002 r. - Prawo o postępowaniu przed sądami administracyjnymi, tekst jednolity: Dz. U. z 2019 r. poz. 2325 z późn. zm.

$4 \quad$ Art. $138 \$ 2$ a i art. $138 \$ 2$ b K.p.a. dodane zostały ustawą z dnia 7 kwietnia 2017 r. o zmianie ustawy Kodeks postępowania administracyjnego oraz niektórych innych ustaw (Dz. U. z 2017 r. poz. 935) zmieniającą K.p.a. z dniem 1 czerwca 2017 r.

5 B. Adamiak, J. Borkowski, Kodeks postępowania administracyjnego. Komentarz, 2019 [baza danych Legalis], Komentarz do art. 138, teza 7 i 11; K. Glibowski, w: Kodeks postępowania administracyjnego. Komentarz, red. R. Hauser, M. Wierzbowski, 2020 [baza danych Legalis], Komentarz do art. 138, teza 2; wyrok NSA z dnia 6 sierpnia 2018 r., II OSK 1797/18, CBOSA. 
kasacyjne organu odwoławczego mają charakter wyjątkowy - zasadą powinno być orzekanie co do istoty sprawy ${ }^{6}$. Decyzja kasacyjna nie rozstrzyga merytorycznie o uprawnieniu lub obowiązku strony, a jedynie nakazuje ponowne przeprowadzenie postępowania administracyjnego przez organ pierwszej instancji ${ }^{7}$.

Decyzję kasacyjną powodującą uchylenie w całości zaskarżonej decyzji i przekazanie sprawy do ponownego rozpatrzenia przez organ pierwszej instancji organ odwoławczy może wydać, gdy decyzja ta została wydana z naruszeniem przepisów postępowania, a konieczny do wyjaśnienia zakres sprawy ma istotny wpływ na jej rozstrzygnięcie. Przekazując sprawę, organ ten powinien wskazać, jakie okoliczności należy wziąć pod uwage przy ponownym rozpatrzeniu sprawy (art. 138 $\$ 2$ K.p.a.).

Konstrukcja prawna decyzji kasacyjnej oparta jest na dwóch kumulatywnych przesłankach: wydaniu decyzji pierwszoinstancyjnej z naruszeniem przepisów postępowania, czyli przepisów K.p.a. lub przepisów o postępowaniu zawartych w ustawach szczególnych, oraz uznaniu przez organ odwoławczy, że konieczny do wyjaśnienia zakres sprawy ma istotny wpływ na jej rozstrzygnięcie ${ }^{8}$. Wydanie decyzji kasacyjnej może nastąpić tylko wtedy, gdy organ pierwszej instancji przeprowadził postępowanie $\mathrm{z}$ rażącym naruszeniem norm prawa procesowego, a w szczególności nie przeprowadził $\mathrm{w}$ ogóle postępowania wyjaśniającego albo postępowanie takie przeprowadzono, ale w rażący sposób naruszono w nim przepisy procesowe ${ }^{9}$. Jak podkreśla się w literaturze, decyzja kasacyjna może być wydana po pierwsze, w sytuacji gdy organ pierwszej instancji w ogóle nie przeprowadził postępowania wyjaśniającego w sprawie, która takiego postępowania wymagała; po drugie, jeżeli organ pierwszej instancji podejmował czynności dowodowe, ale nie wyjaśnił stanu faktycznego sprawy w stopniu umożliwiającym jej prawidłowe rozstrzygnięcie, w szczególności gdy przeprowadzone dowody są nieprzydatne lub niewystarczające w takim

6 B. Adamiak, w: B. Adamiak, J. Borkowski, Postępowanie administracyjne i sq̨owoadministracyjne, Warszawa 2015, s. 277; P. Przybysz, Kodeks postępowania administracyjnego. Komentarz aktualizowany, 2019 [baza danych LEX], Komentarz do art. 138, teza 32. Jak jednak zauważa W. Chróścielewski, analiza orzecznictwa administracyjnego, a zwłaszcza decyzji podejmowanych przez samorządowe kolegia odwoławcze, wskazuje, że decyzje reformacyjne wydawane są o wiele rzadziej niż decyzje kasacyjne. Mamy więc do czynienia z sytuacją rozmijania się poglądów teorii z praktyką. Zob. W. Chróścielewski, Kasacyjny czy reformacyjny model administracyjnego postępowania odwoławczego?, Państwo i Prawo 2015, nr 1, s. 7; wyrok NSA z dnia 25 września 2018 r., II OSK 2352/16, CBOSA.

7 Wyrok WSA w Krakowie z dnia 11 lipca 2017 r., II SA/Kr 1059/17, CBOSA.

8 Wyrok WSA w Gorzowie Wielkopolskim z dnia 4 września 2014 r., II SA/Go 564/14, CBOSA; wyrok WSA w Gdańsku z dnia 7 grudnia 2016 r., II SA/Gd 518/16, CBOSA.

9 Wyrok NSA z dnia 17 czerwca 2011 r., II OSK 1130/10, CBOSA; G. Łaszczyca, w: G. Łaszczyca, Cz. Martysz, A. Matan, Kodeks postepowania administracyjnego. Komentarz, t. 2, Warszawa 2010, s. 229. 
stopniu, że zachodzi konieczność uzupełnienia materiału dowodowego w istotnym zakresie; po trzecie, jeżeli organ pierwszej instancji zgromadził materiał dowodowy w istotnym zakresie z naruszeniem przepisów postępowania administracyjnego, np. zasadniczą część czynności procesowych przeprowadził pracownik podlegający wyłączeniu ze sprawy, strona postępowania nie miała możliwości uskutecznienia swojego prawa do czynnego udziału w postępowaniu; po czwarte w przypadku innych naruszeń przepisów postępowania administracyjnego, które powodują konieczność wyjaśniania sprawy w zakresie mającym istotny wpływ na rozstrzygnięcie, np. gdy organ pierwszej instancji nie zwrócił się do innego organu o zajęcie wymaganego przez prawo materialne stanowiska w trybie art. 106 K.p.a. albo wydał decyzję bez uprzedniego rozstrzygnięcia zagadnienia wstępnego przez inny organ lub sąd, w sytuacji gdy zachodziła podstawa do zawieszenia postępowania $\mathrm{z}$ art. 97 $\$ 1$ pkt 4 K.p.a. ${ }^{10}$.

Natomiast przez istotny wpływ na wynik sprawy należy rozumieć takie działanie, które uzasadnia zmianę treści rozstrzygnięcia ${ }^{11}$. Co do zasady więc przepis ten dotyczy sytuacji, gdy zasada dwuinstancyjności postępowania wyłącza przeprowadzenie w tym zakresie uzupełniającego postępowania dowodowego (art. 136 K.p.a.), gdyż jego zakres wskazuje, że w istocie organ odwoławczy musiałby samodzielnie przeprowadzić postępowanie wyjaśniające odnośnie do kwestii mogących mieć istotny wpływ na treść decyzji. Konsekwencją takiego stanu rzeczy byłoby rozstrzygnięcie sprawy w jednej instancji, a zatem strona nie mogłaby kwestionować wyników postępowania wyjaśniającego w drodze odwołania ${ }^{12}$. Dopiero prawidłowe przeprowadzenie postępowania oraz ustalenie w sposób niebudzący wątpliwości stanu faktycznego sprawy administracyjnej umożliwia właściwe zastosowanie przez organ odpowiednich przepisów prawa materialnego ${ }^{13}$.

Z pola widzenia nie może oczywiście zniknąć fakt, że w aktualnym stanie prawnym organ odwoławczy w decyzji kasacyjnej określa także wytyczne w zakresie wykładni przepisów prawa, które organ pierwszej instancji błędnie zinterpretował w uzasadnieniu zaskarżonej decyzji (art. $138 \$ 2$ a K.p.a.).

W pierwszej kolejności wymaga zwrócenia uwagi kwestia widocznej różnicy pomiędzy użytymi pojęciami w dwóch jednostkach redakcyjnych art. 138 K.p.a. Przepis

10 R. Kędziora, Kodeks postępowania administracyjnego. Komentarz, 2017 [baza danych Legalis], Komentarz do art. 138, Nb. 31.

11 Wyrok NSA z dnia 11 października 2016 r., II OSK 3266/14, CBOSA.

12 Wyrok NSA z dnia 31 marca 2015 r., II OSK 2054/13, CBOSA.

13 J. Wilczyński, Postępowanie ze sprzeciwu od decyzji kasacyjnej jako szczególne postępowanie sąowoadministracyjne. Zakres sq̨dowej kontroli legalności decyzji kasacyjnych, w: Aktualne problemy sądowej kontroli administracji publicznej, red. W. Piątek, 2019 [baza danych LEX]. 
art. $138 \$ 2$ zdanie drugie K.p.a. nakłada na organ odwoławczy bowiem obowiązek wskazania organowi pierwszej instancji, jakie okoliczności należy wziąć pod uwage przy ponownym rozpatrzeniu sprawy, natomiast art. $138 \S 2$ a K.p.a. posługuje się zwrotem „wytycznych” w odniesieniu do wykładni przepisów prawa. Zastosowane pojęcie „wskazać” rozumieć należy jako udzielenie przez organ odwoławczy wskazówek, czyli „konieczność: podania określonych okoliczności; zwrócenia na nie uwagi; udzielenia wyjaśnień, wskazówek czy informacji o określonych okolicznościach; a także wymienienia okoliczności, które należy wziąć pod uwagę przy ponownym rozpatrzeniu sprawy"14. Organ odwoławczy może tylko wskazać, jakie okoliczności stanu faktycznego sprawy mają istotne znaczenie dla jej rozstrzygnięcia, natomiast nie jest dopuszczalne, by przesądzał o treści ponownej decyzji organu pierwszej instancji ${ }^{15}$. Natomiast „wytyczna” to wskazówka określająca sposób działania, jest to więc pojęcie zdecydowanie silniejsze niż termin „wskazówka”. Jej użycie oznacza konieczność sprecyzowania przez organ odwoławczy pewnej ścieżki działań ${ }^{16}$. Wytyczne nie stanowią natomiast źródła prawa powszechnie obowiązującego, są jedynie jego interpretacją, wobec czego nie mają mocy wiążącej dla organów administracji rozstrzygających sprawę ${ }^{17}$. Podkreślić jednak należy, że organ pierwszej instancji nie jest związany ani oceną prawną, ani wskazaniami co do dalszego postępowania, ani wytycznymi co do wykładni zawartymi w decyzji kasacyjnej organu odwoławczego. Ustawodawca nie zastosował bowiem w tych przepisach konstrukcji związania znanej chociażby z art. 110 K.p.a. (związanie organu wydaną decyzją) czy art. 153 ustawy z dnia 30 sierpnia 2002 r. - Prawo o postępowaniu przed sądami administracyjnymi ${ }^{18}$. Przepisy K.p.a. nie przewidują również żadnych sankcji dla organu pierwszej instancji za niezastosowanie się do wskazówek lub wytycznych organu odwoławczego ${ }^{19}$.

Następnie zasygnalizować należy, iż dyskusyjne w doktrynie i orzecznictwie jest, czy wytyczne w zakresie wykładni przepisów dotyczyć mogą zarówno przepisów prawa materialnego, jak i przepisów postępowania, czy też wytyczne mogą się odnosić jedynie do przepisów prawa procesowego. Zgodnie z pierwszym poglądem wytyczne odnosić się mogą do obu rodzajów przepisów. W ramach kompetencji organu odwoławczego mieszczą się bowiem takie uprawnienia jak wskazanie

14 J. Zaporska-Frankiewicz, Z. Wardak, Związanie ocena prawną, wskazaniami co do dalszego postępowania oraz wytycznymi w zakresie wykładni przepisów prawa w ogólnym postępowaniu administracyjnym, Zeszyty Naukowe Sądownictwa Administracyjnego 2020, nr 2, s. 29.

15 R. Kędziora, Kodeks postępowania..., Komentarz do art. 138, Nb. 37.

16 J. Zaporska-Frankiewicz, Z. Wardak, Związanie ocena..., s. 29.

17 Tamże, s. 34.

18 Dz. U. z 2019 r. poz. 2325 z późn. zm.

19 J. Zaporska-Frankiewicz, Z. Wardak, Związanie oceną..., s. 34. 
czynników, które trzeba uwzględnić, dokonując interpretacji pojęć nieostrych czy zdefiniowanie relacji zachodzących pomiędzy odnoszącymi się do sprawy uregulowaniami prawa materialnego ${ }^{20}$. Za dopuszczalnością określania przez organ odwoławczy wytycznych w obu przypadkach przemawiać ma również brak wyrażonego $\mathrm{w}$ art. $138 \$ 2 \mathrm{a}$ K.p.a. expressis verbis rodzaju przepisów, jakich wytyczne mogą dotyczyćc ${ }^{21}$. W judykaturze spotykane są również orzeczenia, w których wskazuje się, że prawnie koniecznym warunkiem podjęcia rozstrzygnięcia kasatoryjnego na podstawie art. $138 \$ 2$ K.p.a. jest uprzednie dokonanie rekonstrukcji normy prawa materialnego, adekwatnej dla danej sprawy administracyjnej (przedmiotu postępowania) i następcze dokonanie jej interpretacji. Dopiero wtedy będzie możliwe prawidłowe zidentyfikowanie faktów prawotwórczych dla danej sprawy administracyjnej. Stąd w uzasadnieniu decyzji istotną rolę odgrywać mają nieobarczone błędem wytyczne w zakresie interpretacji przepisów, mogących znaleźć zastosowanie w sprawie, ponieważ to normy prawa materialnego konkretyzują przedmiot postępowania administracyjnego i wiążąco kształtują sytuację prawną jej adresata ${ }^{22}$.

Zgodnie $\mathrm{z}$ drugim poglądem prezentowanym $\mathrm{w}$ doktrynie przedmiotowe wytyczne „mogą dotyczyć tylko przepisów postępowania, które organ administracji błędnie zinterpretował w uzasadnieniu zaskarżonej decyzji, a w konsekwencji nieprawidłowo zastosował [...]. W sytuacji gdy przesłanką wydania decyzji kasacyjnej jest stwierdzenie wydania decyzji pierwszej instancji z naruszeniem przepisów postępowania, to nie powinno być wątpliwości, że zakres wskazanych wytycznych jest ograniczony do tych i tylko tych przepisów postępowania, których naruszenie zostało stwierdzone. Formułowanie przez organ odwoławczy wytycznych w zakresie prawa materialnego, które zostały błędnie zinterpretowane w uzasadnieniu zaskarżonej decyzji, jest zdecydowanie przedwczesne, ponieważ odnoszą się one do nieustalonego jeszcze stanu faktycznego i nie jest pewne, że te przepisy zostaną zastosowane przy ponownym rozpatrzeniu sprawy przez organ pierwszej instancji”23. Również w orzecznictwie sądowoadministracyjnym podzielany jest powyższy pogląd, wskazując, że decyzja organu odwoławczego wydana na podstawie art. 138 $\$ 2$ K.p.a. nie kształtuje stosunku materialnoprawnego, a konsekwencją wydania

20 Z. Kmieciak, w: Kodeks postępowania administracyjnego. Komentarz, red. W. Chróścielewski, 2019 [baza danych LEX], Komentarz do art. 138, teza 5.

21 J. Zaporska-Frankiewicz, Z. Wardak, Związanie ocena..., s. 34.

22 Wyrok WSA w Gdańsku z dnia 23 listopada 2020 r., II SA/Gd 808/20, CBOSA; wyrok NSA z dnia 26 listopada 2019 r., II OSK 3080/19, CBOSA.

23 A. Wróbel, w: Komentarz aktualizowany do Kodeksu postępowania administracyjnego, red. M. Jaśkowska, M. Wilbrandt-Gotowicz, A. Wróbel, 2020 [baza danych LEX], Komentarz do art. 138, teza 13. 
decyzji kasacyjnej jest powrót sprawy do postępowania przed organem pierwszej instancji ${ }^{24}$.

Niezależnie jednak od przyjętego poglądu w powyższej kwestii nie ulega wątpliwości, że wytyczne odnosić się mogą wyłącznie do tych przepisów prawa materialnego lub przepisów postępowania, które organ pierwszej instancji błędnie zinterpretowal ${ }^{25}$ (przepis art. $138 \$ 2 \mathrm{a}$ K.p.a. in fine stanowi bowiem: „Jeżeli organ pierwszej instancji dokonał w zaskarżonej decyzji błędnej wykładni przepisów prawa...”). Oznacza to, że wytyczne nie mogą dotyczyć przepisów, których organ pierwszej instancji nie interpretował, a które mogłyby mieć zdaniem organu odwoławczego zastosowanie w sprawie. I w tym kontekście jako aktualną uznać można tezę glosowanego orzeczenia NSA. W przeciwnym razie organ odwoławczy byłby bowiem zobowiązany do dokonania interpretacji wszystkich przepisów prawa materialnego potencjalnie mogących mieć zastosowanie w badanej sprawie w momencie, gdy w ramach ponownego rozpatrzenia sprawy organ pierwszej instancji będzie dopiero ustalał kompletny i w sposób prawidłowy stan faktyczny sprawy.

Znaczenie poglądu wyrażonego $\mathrm{w}$ glosowanym orzeczeniu NSA jest również istotne z punktu widzenia zasad ustalania statusu strony postępowania administracyjnego. Zgodnie z art. 28 K.p.a. stroną jest każdy, czyjego interesu prawnego lub obowiązku dotyczy postępowanie albo kto żąda czynności organu ze względu na swój interes prawny lub obowiązek. Źródłem interesu prawnego musi być norma prawa materialnego, na podstawie której w postępowaniu administracyjnym określony podmiot $\mathrm{w}$ określonym stanie faktycznym może domagać się konkretyzacji jego uprawnień lub obowiązków bądź żądać przeprowadzenia kontroli określonego aktu lub czynności w celu ochrony jego sfery praw i obowiązków przed naruszeniami dokonanymi tym aktem i doprowadzenia tego aktu do stanu zgodnego z prawem $^{26}$. Przyznanie statusu strony wymaga najpierw przeprowadzenia czynności wyjaśniających przy udziale jednostki. Organ prowadzący postępowanie - w myśl zasady prawdy obiektywnej wyrażonej w art. 7 K.p.a. oraz zgodnie z art. 77 K.p.a. jest obowiązany do wyczerpującego i pełnego ustalenia stanu faktycznego sprawy, a następnie dokonania jego prawnej oceny ${ }^{27}$. Skoro organ odwoławczy uznaje, że zachodzi konieczność uchylenia decyzji i przekazania sprawy do ponownego rozpatrzenia ze względu na naruszenie przepisów postępowania, to znaczy, że nie ma

24 Wyrok NSA z dnia 9 maja 2017 r., II OSK 2219/15, CBOSA; wyrok WSA w Warszawie z dnia 21 listopada 2019 r., VIII SA/Wa 737/19, CBOSA; wyrok WSA w Bydgoszczy z dnia 12 listopada 2020 r., II SA/Bd 809/20, CBOSA.

25 J. Zaporska-Frankiewicz, Z. Wardak, Zwiazanie ocena..., s. 31.

26 Wyrok WSA w Warszawie z dnia 22 marca 2019 r., IV SA/Wa 73/19, CBOSA.

27 Wyrok WSA w Poznaniu z dnia 29 sierpnia 2018 r., IV SA/Po 332/18, CBOSA. 
jeszcze podstaw do definitywnego przesądzenia o istnieniu bądź braku istnienia interesu prawnego podmiotu $\mathrm{w}$ danej sprawie. Należy bowiem mieć na uwadze, że organy administracyjne zobowiązane są do ustalania prawidłowego kręgu stron na każdym etapie postępowania administracyjnego ${ }^{28}$, a finalnie status strony w postępowaniu administracyjnym ocenia się według przepisów prawa materialnego obowiązujących w dacie wydania decyzji ostatecznej kończącej to postępowanie ${ }^{29}$.

Mając powyższe na uwadze, słuszne - w ocenie glosatora, który podziela w tym zakresie stanowisko NSA - jest sformułowanie, że organ odwoławczy nie rozstrzyga o meritum sprawy ani nie przeprowadza merytorycznej kontroli decyzji wydanej przez organ pierwszej instancji, gdyż wydając decyzję kasacyjną, wskazuje właśnie na konieczność przeprowadzenia w określonym zakresie lub w całości postępowania wyjaśniającego celem poczynienia ustaleń niezbędnych do prawidłowego rozstrzygnięcia sprawy. Powyższe koresponduje z poglądami NSA prezentowanymi w innych orzeczeniach wskazującymi, że co prawda przepis art. $138 \$ 2$ K.p.a. nakazuje organowi odwoławczemu zawarcie w decyzji kasacyjnej wskazań co do tego, jakie okoliczności należy wziąć pod uwagę przy ponownym rozpatrzeniu sprawy, jednakże nie mogą one dotyczyć tego, jakie rozstrzygnięcie ma być wydane po ponownym rozpoznaniu. Mogą one jedynie stanowić „podpowiedź” organu odwoławczego, aby organ pierwszej instancji dokonał rozważań w zakresie wskazanych okoliczności i w tej kwestii przeprowadził stosowne postępowanie wyjaśniające, wykorzystując już zgromadzony materiał dowodowy, jak też dopuszczając ewentualnie w razie potrzeby nowe dowody. Natomiast organ odwoławczy przekazując sprawę do ponownego rozpatrzenia organowi pierwszej instancji, nie może narzucać mu treści rozstrzygnięcia ${ }^{30}$. Decyzja kasacyjna jest decyzją wyłącznie o charakterze formalnym i nie powinna odnosić się do istoty sprawy, a więc nie jest prawidłowe wypowiadanie się w niej co do kwestii dotyczących zastosowania właściwej normy prawa materialnego, w kontekście pozytywnego lub negatywnego rozstrzygnięcia o obowiązkach adresata decyzji ${ }^{31}$.

W kontekście glosowanego orzeczenia przypomnieć ponadto należy, że organ odwoławczy może wydać decyzję kasacyjną, gdy organ pierwszej instancji przy rozpatrywaniu sprawy nie przeprowadził postępowania wyjaśniającego w ogóle lub naruszył przepisy postępowania w stopniu uzasadniającym uznanie sprawy za

28 Wyrok NSA z dnia 20 września 2017 r., II OSK 70/16, CBOSA.

29 P. Gołaszewski, w: Kodeks postępowania administracyjnego. Komentarz, red. R. Hauser, M. Wierzbowski, 2020 [baza danych Legalis], Komentarz do art. 28, Nb. 39 wraz z powołanym tam orzecznictwem.

30 Por. wyroki NSA z dnia 5 marca 1990 r., IV SA 564/89, Prawo i Życie 1991, nr 3, s. 15; z dnia 25 listopada 2016 r., I OSK 3165/14, CBOSA; z dnia 24 stycznia 2018 r., I OSK 1902/15, CBOSA.

31

Wyrok WSA w Białymstoku z dnia 10 stycznia 2020 r., II SA/Bk 821/19, CBOSA. 
niewyjaśnioną i przez to niekwalifikującą się do merytorycznego rozstrzygnięcia przez organ drugiej instancji ${ }^{32}$. Oznacza to, że organ pierwszej instancji dopuszczając się powyższych uchybień, nie poczynił dostatecznych działań w celu ustalenia prawidłowego stanu faktycznego sprawy. To $z$ kolei powoduje, że nie można wskazać, jakie przepisy prawa materialnego należało zastosować w sprawie. Stan faktyczny sprawy jest wynikiem postępowania dowodowego, czyli zastosowania przepisów postępowania, a stosowanie prawa materialnego (subsumcja) ma miejsce wówczas, gdy stan faktyczny sprawy jest już ustalony w pełnym zakresie i w sposób niewadliwy. Wobec powyższego działanie organu odwoławczego polegające na wypowiadaniu się w uzasadnieniu decyzji kasacyjnej o ewentualnym naruszeniu prawa materialnego lub interesu prawnego strony uznać należałoby za wewnętrznie sprzeczne i niekonsekwentne. Organ odwoławczy z jednej strony wypowiadałby się bowiem w przedmiocie naruszeń prawa materialnego (co oznaczałoby, że nie kwestionuje stanu faktycznego sprawy), a jednocześnie na podstawie art. $138 \$ 2$ K.p.a. uchylałby decyzję organu pierwszej instancji i przekazywał do ponownego rozpatrzenia $\mathrm{z}$ uwagi na to, że decyzja wydana została z naruszeniem przepisów postępowania, a konieczny do wyjaśnienia zakres sprawy miał istotny wpływ na jej rozstrzygnięcie.

Przeprowadzone rozważania dotyczące komentowanego wyroku NSA pozwalają zatem stwierdzić, że wskazany wyżej zakaz wypowiadania się w decyzji kasacyjnej przez organ odwoławczy o ewentualnym naruszeniu przepisów prawa materialnego lub interesu prawnego strony skarżącej powoduje, że żadna jednostka nie zostanie przedwcześnie pozbawiona możności dochodzenia obrony swoich praw podmiotowych. Wobec tego należy podzielić pogląd wyrażony w omawianym orzeczeniu NSA, że decyzja kasacyjna nie może spowodować niekorzyści „materialnej” dla strony. W innym bowiem przypadku mogłoby nawet dochodzić do obchodzenia zakazu reformationis in peius ${ }^{33}$, gdyby w następstwie wiążących wytycznych organu odwoławczego w przedmiocie braku istnienia interesu prawnego strona, która wniosła odwołanie, zostałaby wyłączona z czynnego udziału w postępowaniu przed organem pierwszej instancji przy ponownym rozpatrzeniu sprawy. Tym bardziej że przepis art. 139 K.p.a. nie ma zastosowania przy rozpatrywaniu sprawy przez organ

32 Wyrok NSA z dnia 14 lutego 2017 r., II OSK 1386/15, CBOSA.

33 W doktrynie i literaturze dominuje trafny pogląd, że zakaz reformationis in peius nie ma zastosowania, w sytuacji gdy organ odwoławczy wydaje decyzję kasacyjną z art. $138 \$ 2$ K.p.a. Słusznie się bowiem podkreśla, że organ odwoławczy nie przesądza ostatecznie o rozstrzygnięciu sprawy, a jedynie przekazuje jej rozpatrzenie organowi pierwszej instancji. A. Golęba w: Kodeks postępowania administracyjnego. Komentarz, red. H. Knysiak-Molczyk, 2019 [baza danych LEX], Komentarz do art. 139, teza 4; wyrok NSA z dnia z 23 maja 2013 r., II OSK 231/12 oraz z dnia 12 stycznia 2018 r., II OSK 772/16, CBOSA. 
pierwszej instancji w postępowaniu toczącym się w następstwie kasacyjnej decyzji organu odwoławczego wydanej na podstawie art. $138 \$ 2$ K.p.a. ${ }^{34}$.

Reasumując przedstawione powyżej wywody, rozstrzygnięcie przedstawione w glosowanym wyroku NSA należy ocenić jako pozytywne i aktualne z uwzględnieniem zmian wynikających z wprowadzenia przepisu art. $138 \$ 2$ a K.p.a. wpływającego na sposób interpretacji art. $138 \$ 2$ K.p.a. Podyktowane to jest charakterem i zakresem decyzji kasacyjnej, która powoduje przekazanie sprawy do ponownego rozpatrzenia przez organ pierwszej instancji ze względu na spostrzeżone uchybienia przepisów procesowych w jego postępowaniu. Dlatego organ odwoławczy w decyzji kasacyjnej nie powinien wypowiadać się na temat materialnoprawnych podstaw wydania decyzji przez organ pierwszoinstancyjny. Organ odwoławczy nie powinien również w uzasadnieniu decyzji kasacyjnej wyrażać swojego stanowiska o słuszności bądź braku jej wydania przez organ takiego czy innego rozstrzygnięcia o prawach lub obowiązkach strony, przeprowadzone postępowanie bowiem miało istotne wady, a to uniemożliwiało wydanie merytorycznie poprawnego rozstrzygnięcia.

\section{Bibliografia}

Adamiak B., Borkowski J., Kodeks postępowania administracyjnego. Komentarz, 2019 [baza danych Legalis], Komentarz do art. 138, teza 7 i 11.

Adamiak B., w: B. Adamiak, J. Borkowski, Postępowanie administracyjne i sqdowoadministracyjne, Warszawa 2015.

Chróścielewski W., Kasacyjny czy reformacyjny model administracyjnego postępowania odwoławczego?, Państwo i Prawo 2015, nr 1.

Glibowski K., w: Kodeks postępowania administracyjnego. Komentarz, red. R. Hauser, M. Wierzbowski, 2020 [baza danych Legalis], Komentarz do art. 138, teza 2.

Golęba A., w: Kodeks postępowania administracyjnego. Komentarz, red. H. Knysiak-Molczyk, 2019 [baza danych LEX], Komentarz do art. 139, teza 4.

Gołaszewski P., w: Kodeks postępowania administracyjnego. Komentarz, red. R. Hauser, M. Wierzbowski, 2020 [baza danych Legalis], Komentarz do art. 28, Nb. 39.

Kędziora R., Kodeks postępowania administracyjnego. Komentarz, 2017 [baza danych Legalis], Komentarz do art. 138, Nb. 31.

Kmiecik Z.R., Interes prawny stron w postępowaniu administracyjnym, Państwo i Prawo 2013, nr 1.

Łaszczyca G., w: G. Łaszczyca, Cz. Martysz, A. Matan, Kodeks postępowania administracyjnego. Komentarz, t. 2, Warszawa 2010.

34 Zob. uchwałę NSA(7) z dnia 4 maja 1998 r., FPS 2/98, ONSA 1998, nr 3, poz. 79. 
Przybysz P., Kodeks postępowania administracyjnego. Komentarz aktualizowany, 2019 [baza danych LEX], Komentarz do art. 138, teza 32.

Wilczyński J., Postępowanie ze sprzeciwu od decyzji kasacyjnej jako szczególne postępowanie sądowo administracyjne. Zakres sądowej kontroli legalności decyzji kasacyjnych, w: Aktualne problemy sadowej kontroli administracji publicznej, red. W. Piątek, 2019 [baza danych LEX].

Wróbel A., w: Komentarz aktualizowany do Kodeksu postępowania administracyjnego, red. M. Jaśkowska, M. Wilbrandt-Gotowicz, A. Wróbel, 2019 [baza danych LEX], Komentarz do art. 138, teza 13.

Zaporska-Frankiewicz J., Wardak Z., Związanie ocena prawna, wskazaniami co do dalszego postępowania oraz wytycznymi w zakresie wykładni przepisów prawa w ogólnym postępowaniu administracyjnym, Zeszyty Naukowe Sądownictwa Administracyjnego 2020, nr 2. 